som »den klarøjede og lydhøre Hejmdal«. Også Johan Johansen betoner, at Grundtvig »på underligste vis arbejder sig ind i sin samtid«(s. I2), men han vil dog hævde, at det er i kraft af »en poetisk-realistisk synskhed « disse foredrags billede af Danmark og det hele, gamle Europas kulturverden hævder sig, så »Mands Minde« står som »et hovedværk i dansk digtning, så at sige blomsten af det danske folks erkendelsesformåen, kraftigere end noget andet af vor litteraturs testamenter《 (s. 24).

I en række velskrevne, stærkt personligt engagerede betragtninger søger forfatteren at retfærdiggøre sin høje vurdering af disse taler, der karakteriseres som »en skole i sjælelig sundhed«, føst og fremmest fordi »Grundtvigs menneskelighed ikke er forældet«. Johan Johansen ejer noget af den kombination af utrættet tolkningsevne med en lyst til at beundre, som efter hans skøn er en væsentlig egenskab hos Grundtvig. Fremstillingen er, trods stedvis kritik - især af »den patriotiske livsforklaring « hos Grundtvig, båret af varme og af vilje til at gribe Grundtvigs intention og bliver derved et frisk oplæg til debat om Grundtvigs tanker.

Bogens sidste afsnit: »Grundtvigs billede« giver på basis af hans brevveksling en skildring af hans livsholdning. Han personificerer et helt folks anstrengelser for at vinde frem til et videnskabeligt stade med samvittigheden og troen i behold. »Der er ingen, der med større og stadigere fatning og klarhed end Grundtvig gør sig regnskab for, hvad han mener og hvorfor. I sin livserfarne fatning og klarhed overgår han langt vore dages fremragende »hjerner«. Hans vederhæf tighed (objektivitet) er usvigelig, prøvet »overfor døden «, øst af livet, sanset og følt« (s. I I6). Han blev derved efter forfatterens mening »den betydeligste af vore digtere, paa samme tid den mest moderne og mest gammeldags aand i det I9. aarhundredes Danmark « (s. 103).

Johan Johansens arbejde på at »genfinde Grundtvig $\mathrm{i}$ hans menneskelighed og ligesom evige ungdommelighed « sker under opgør til to sider: dels mod Grundtvigs »tilhængere« - forfatteren vil »ligesom prøve at frelse ham fra højskolen og folkekirken « - dels mod hans modstandere - den aversion mod Grundtvig, som prægede gymnasiets litteraturundervisning i forfatterens ungdom (s. I 20), er blevet ham et incitament. Skønt meget i bogen er uafklaret, er den rig på stof til overvejelse og ofte forfriskende $\mathrm{i}$ sin kritik både af den konventionelle og aversionelle opfattelse af Grundtvig.

Henning Hoirup.

Otto Holmgaard: Peter Christian Kierkegaard. Grundtvigs Larling. Rosenkilde og Bagger, København 1953.

P. C. Kierkegaard har længe i dansk åndshistorie stået som en vel uforglemmelig, men dog mærkeligt uigennemtrængelig skikkelse, en gådernes mand, $\mathrm{i}$ hvis sind de dybe afgrunde uberegneligt kunne åbne sig. Skønt der i årene 1902-I905 fremkom en udgave af hans Samlede Skrifter (ved Poul Egede Glahn og Lavrids Nygård), har hans forfatterskab så godt som ikke været 
genstand for dansk teologis opmærksomhed. Det må derfor hilses med glæde, at forskningens søgelys nu retter sig mod hans gerning og tanker.

Som undertiden antyder og forordet understreger har provst Holmgaard lagt hovedvægten på at skildre biskop Kierkegaard »som ikke blot Kirkens, men ogsaa den kirkelige Anskuelses Forsvarer« samt på at redegøre for hans spændingsfyldte forhold til broderen Søren Kierkegaard, men derimod ikke tilsigtet at skrive »en endelig biografisk Fremstilling « med lige vægt på alle livsfaser. De således anlagte aspekter er utvivlsomt både frugtbare for belysningen af P.C. Kierkegaards personlighed og centrale for forståelsen af hans kirkelige stade. Værkets stærke koncentration om forholdet til Grundtvig og broderen giver det både dets styrke: den faste og klare optrækning af portrættets hovedlinier, og dets svaghed: at nuancerne i biskop Kierkegaards karakter i nogen grad træder tilbage, fordi hans levned iøvrigt er så kortfattet behandlet.

Medens Søren Kierkegaards forhold til Grundtvig må betegnes som episodisk og kun afsatte et ganske vist heftigt irritament (se Carl Weltzer: Grundtvig og Søren Kierkegaard, 1952), blev P.C. Kierkegaard positivt, dybtgående og varigt påvirket, og hans splittede, dialektiske natur fandt i Grundtvigs kirkelige anskuelse det fundament, han savnede; han vedgår $\mathrm{i}$ sit sidste brev til Grundtvig ( ${ }^{12 / 2}$ 1872), at han nu og da har haft »vanskeligt ved at finde mig i »Grundtvigianere«, som de vel ogsaa ofte i mig, men at jeg aldrig har glemt eller sveget det mig altid Allervigtigste af det Meget, jeg lærte hos Grundtvig «.

Allerede i sin disputats De theologia vere Christiana træder P. C. Kierkegaard frem som Grundtvigs våbendrager, idet han ikke blot drister sig til at citere Grundtvig (bl. a. »Kirkens Gjenmæle«), men plæderer for »at bygge hele Theologien paa Kirke-Ordet« (som Grundtvig selv med rette refererer i brev til G. Busck $2 / 2$ 1836). Det hedder i disputatsen, at »livets ord, som lyder i sakramenterne, og som gennem troen har taget bolig i menneskene«, er den grundvold, som Herren een gang har lagt og som teologien skal bygge på, idet den nærmere udvikles efter skriften. I en række senere afhandlinger, stridsindlæg og patristiske studier går Kierkegaard gang på gang i skranken for Grundtvig, ligesom Melanchton for Luthers tanker (som det træffende hedder s. 37). Forbindelsen mellem Grundtvigs og hans »lærlings« teologi trækkes (især $\mathrm{i}$ indledningen til afsnittet »Den kirkelige Anskuelses lærde Forsvarer «) kort op og der redegøres overskueligt for hovedindholdet i denne - så væsentlige - gruppe af P.C. Kierkegaards litterære arbejder, skrevet som teologisk underbygning for Grundtvigs kirketanker. Man kunne have ønsket en udførligere behandling, men forfatteren har åbenbart ikke villet overbelaste sin fremstilling; Kierkegaard vedgik selv at være $\gg$ tungmælet i Pennen«, og det er givet, at en mere indgående undersøgelse af hans forfatterskab uvægerlig ville kollidere med det mål, som Holmgaard har sat sig og helt igennem fastholder: at give en indføring i P. C. Kierkegaards tanker, som kan læses af enhver, der har interesse for vor folkekirke.

Dette anlæg af skildringen er så meget mere på sin plads som biskop Kierkegaard med rette fortjener at kendes af vide kredse som mærkesmand i folkekirkens historie. Gik der en professor tabt i ham - universitetet holdt 
som bekendt både ham og andre disciple af Grundtvig ude - blev der til gengæld vundet en præst af karat. Som forkæmper for kirkelig frihed blev han kendt fra 1842 , da han nægtede at tvangsdøbe børn af baptister, og endnu dybere indskrev han sit navn $\mathrm{i}$ kirkehistorien, da han som Danmarks første grundtvigske biskop (1856-75) gik ind for de kirkelige frihedslove, som alle de andre bisper skarpt modsatte sig, i frygt for at de tilsidst ville medføre »at der ingen Folkekirke findes i Danmark «.

Under disse kampe, hvori Kierkegaard som biskop og især som kultusminister fik så indgribende betydning, udviklede han sit syn på kirken som folkekirke. Dette ord, som i juni-grundloven fik borgerret i vort sprog, skyldes ham (han brugte det første gang i I84I, se s. I03). I sit syn på folkekirken ligger han meget til højre for Grundtvig, som hyppigt... også i sine sidste år - overvejede udtrædelse af folkekirken, hvis fuld frihed, herunder »præstefrihed «, ikke blev opnået. Kierkegaard, derimod, kunne sige: »Jeg elsker Folkekirken som tugtende, støttende og trøstende - Hvor mat og sløvt derfor det end stundom kan gaae i Folkekirken, den er dog Bæreren til os og vore Børn af vore Fædres Tro, i hvilken vi kunne omgives og omtones af Kristi Røst... Det er derfor, jeg kæmper for Folkekirken«. De aktstykker, Holmgaard har fremdraget, tjener til uddybelse af vor viden om Kierkegaards rolle i kirkepolitikken, og kapitlet »Kirkeligt Syn og Virke« er skrevet med en indsigt og samhu, som gør det til et af de bedste $\mathrm{i}$ bogen.

Lige så veldokumenteret og velskrevet er bogens længste afsnit: »Søren Kierkegaard«. Den tragiske udvikling i brødrenes forhold havde flere årsager, men en væsentlig var sikkert forskellen mellem biskoppens grundtvigske, objektive forståelse af kristendommen og filosoffens subjektive; oplysende er især det s. 72 bragte citat af Søren Kierkegaards dagbog, hvis hadefulde udfald mod broderen iøvrigt er legio. Det hedder f. eks. i dagbogen for juli I855, at ligesom nogle ikke kan udstå drankere, fordi de dunster af brændevin, er det S. K. ubehageligt at læse Grundtvigianeres skriverier, fordi de er »indhyllet $i$ en Dunst af Hjertelighed; og Pastor Lic. Kierkegaard er endog blandt Grundtvigianere en af de stærkest dunstende«. Det tjener Peter Kierkegaard til ære, at han - trods sin saglige kritik af det skæve og ensidige i broderens værker - roligt og rigtigt kunne sige derom: »En Times Læsning i dem gør paa mig næsten ganske samme Virkning, som tidligere et Styrtebad i Henseende til mit legemlige Befindende. Et Øjeblik snapper Livet i mig ligesom efter Luft, og derpaa ander jeg igen dybt og frit i Troens friske Luftninger, medens Tankens Friskarer paa een Gang finder tilbage til deres underordnede Stilling som Livets Tjenere, og Hovedet igen finder sig $i$ at være Hoved istedetfor at ville være det hele Menneske« (s. 75, foredrag for Roskilde Konvent 30/10 1849).

Det vigtigste fund, forfatteren har gjort hvad P. C. Kierkegaards stilling til broderen angår, er de hidtil ikke fremdragne optegnelser vedrørende det bekendte foredrag i Roskilde Konvent 5/7 1855 . På grund af Søren Kierkegaards tragiske død samme efterår fremkom dette foredrag aldrig, og referatet af de to fyldige manuskripter (i Ny kgl. Saml. 3005, $4^{\circ}$, VII, se Holmgaards skrift s. 78-87) er derfor af allerstørste interesse. Der er forment- 
lig hverken i datiden eller siden fremført så vægtig en gendrivelse af Søren Kierkegaards angreb på kirken $\mathrm{i}$ » Øjeblikket«.

Otto Holmgaards bog giver læseverdenen en længe savnet indføring i Peter Christian Kierkegaards gerning og forfatterskab. Den er forsynet med kildehenvisninger, som viser vejen for dem, der vil gå i lag med det selvstudium af forfatterskabet, som fremstillingen så varmt indbyder til.

\section{Henning Høirup.}

Harry Aronson: Mänskligt och kristet. En studie i Grundtvigs teologi. Skrifter udgivet af Grundtvig-Selskabet XI (Scandinavian University Books. Svenska Bokförlaget, Bonniers, Stockholm. 1960).

Denne afhandling, som med megen hæder blev forsvaret for doktorgraden den 7. maj i år i Carolinasalen på Lunds Universitet, er den første rent systematiskteologiske Grundtvig-disputats i Norden. Det er den hidtil udførligste behandling af den ældre Grundtvigs teologi og et vægtigt og selvstændigt bidrag til forståelsen af dennes ærinde og egenart. Fremstillingen er oftest enkel og knap, lettere læselig end de stofrige grundtvigske kilder, hvis tanker her er underkastet en energisk koncentration; på visse punkter rejser det spørgsmål sig dog, om ikke den opnåede enkelhed skyldes en uholdbar forenkling af Grundtvigs standpunkter.

Det er i alt væsentligt lykkedes Aronson at overvinde de vanskeligheder, som Grundtvigs forfatterskab altid har haft ord for at frembyde for andre nationers tilegnelse - sidst udtrykt af Ragnar Bring ( $\mathrm{i}$ en forelæsning om »Det levende Ordet«): Om Grundtvig bör enligt min mening en dansk tala, och ingen annan än den som helt lever i danskt »åndsliv« kan väl rätt återge det grundtvigska.« - Grundtvig er på een gang den mest udpræget danske og den mest universelle af vore kirkemænd i det 19. århundrede. Hans opfattelse af det særligt folkelige som udtryk for skabelsen og hans klare blik for det fælles kristelige i læren om frelsen er polerne, som betinger spændingen i hans tænkning og særpræget $\mathrm{i}$ hans digtning. Den dermed givne problematik er afgørende for hans teologiske grundsyn. Afhandlingens emne: Grundtvigs bestemmelse af forholdet mellem det menneskelige og det kristelige, mellem folk og kirke, er således centralt valgt.

Bogens fodnoter frembyder et meget nyttigt florilegium af Grundtvig-ord om det behandlede emne, idet alle væsentlige tekster aftrykkes på dansk. De fejl, der er indløbet - især som følge af sætningen $i$ et svensk trykkeri - er praktisk talt alle ubetydelige (f. eks. s. 30, note 42 slutningen: Trohet for Troskab; s. 83, øverste note: fuldmogen for fuldmoden; s. 151, sidste note: oforanderlige for $u$ foranderlige osv.). S. 49, note 90, næstsidste afsnits 3 . sidste linie er der faldet fire ord ud: efter »end mellem « mangler »den alt givende og «. S. 251, næstsidste linie i noten skal »hade« være »havde«.

Hvad værkets metodik angår, lader forfatteren principielt spørgsmålet om begrebers og tankers genesis og udvikling hvile (enkelte steder tales der dog om en vis affinitet mellem Grundtvigs tanker og tidens gængse evolutionisme, 